\title{
Rheological and diffusion properties of a dextran-con a polymer in the presence of insulin and magnesium
}

\author{
Gary G. Adams • Yuxin Cui • John H. Mitchell • \\ M. Joan Taylor
}

Published online: 18 October 2006

(C) Springer-Verlag 2006

Unfortunately due to technical errors the references were not published completely. The complete references are the following. The publisher apologizes for this mistake.

\section{References}

Agrawal BB, Goldstein IJ, Hassing GS, So LL (1968) Proteincarbohydrate interaction. XVIII. The preparation and properties of acetylated concanavalin A, the hemagglutinin of the jack bean. Biochemistry 7(12):4211-4218

Arata T, Okitsu T, Fukazawa T, Ikeda H, Kobayashi K, Yong C, Kosaka Y, Narushima M, Matsuoka J, Yamamoto I, Tanaka N, Lakey JR, Kobayashi N (2004) Maintenance of glucose-sensitive insulin secretion of cryopreserved human islets with University of Wisconsin solution and ascorbic acid-2 glucoside. Artif Organs 28(6):529-536

Becker JW, Reeke GN Jr, Wang JL, Cunningham BA, Edelman GM (1975) The covalent and three-dimensional structure of concanavalin A. III. Structure of the monomer and its interaction with metals and saccharides. J Biol Chem 250(4):1513-1524

The online version of the original article can be found at http://dx.doi. org/10.1007/s00397-005-0013-y

G. G. Adams $(\bowtie) \cdot$ Y. Cui

Insulin Diabetes Experimental Research Group,

Faculty of Medicine and Health Science,

University of Nottingham,

Clifton Boulevard,

NG7 2UH Nottingham, UK

e-mail: Gary.Adams@nottingham.ac.uk

\section{J. H. Mitchell}

Division of Food Sciences, University of Nottingham,

Sutton Bonington Campus,

LE12 5RD Loughborough, Leics, UK

\section{J. Taylor}

Leicester School of Pharmacy, De Montfort University,

The Gateway,

LEI 9BH Leicester, UK
Becker JW, Reeke GN Jr, Cunningham BA, Edelman GM (1976) New evidence on the location of the saccharide-binding site of concanavalin A. Nature 259(5542):406-409

Bergeron L, Filobelo LF, Galkin O, Vekilov PG (2003) Thermodynamics of the hydrophobicity in crystallization of insulin. Biophys J 85(6):3935-3942

Bouckaert J, Loris R, Wyns L (2000a) Zinc/calcium- and cadmium/ cadmium-substituted concanavalin A: interplay of metal binding, $\mathrm{pH}$ and molecular packing. Acta Cryst D Biol Crystallogr 56:1569-1576

Bouckaert J, Dewallef Y, Poortmans F, Wyns L, Loris R (2000b) The structural features of concanavalin A governing non-proline peptide isomerization. J Biol Chem 275(26):19778-19787

Brange J (1987) Galenics of insulin - the physico-chemical and pharmaceutical aspects of insulin and insulin preparations. Springer-Verlag, Berlin Heidelberg New York

Brange J, Langkjoer L (1993) Insulin structure and stability. Pharm Biotechnol 5:315-350

Brewer C, Bhattacharyya L, Brown RD III, Koenig SH (1985) Interactions of concanavalin A with a trimannosyl oligosaccharide fragment of complex and high mannose type glycopeptides. Biochem Biophys Res Commun 127(3):1066-1071

Cunningham BA, Wang JL, Waxdal MJ, Edelman GM (1975) The covalent and three-dimensional structure of concanavalin A. II. Amino acid sequence of cyanogen bromide fragment F3. J Biol Chem 250(4):1503-1512

Ende N, Chen R, Reddi AS (2004) Transplantation of human umbilical cord blood cells improves glycemia and glomerular hypertrophy in type 2 diabetic mice. Biochem Biophys Res Commun 321(1):168-171

Flocco MM, Mowbray SL (1994) Planar stacking interactions of arginine and aromatic side-chains in proteins. J Mol Biol 235 (2):709-717

Fong TM, Cascieri MA, Yu H, Bansal A, Swain C, Strader CD (1993) Amino-aromatic interaction between histidine 197 of the neurokinin-1 receptor and CP 96345. Nature 362(6418): 350-353

Goldstein IJ, Hollerman CE, Smith EE (1965) Protein-carbohydrate interaction. II. Inhibition studies on the interaction of concanavalin A with polysaccharides. Biochemistry 4:876-883

Goldstein IJ, Reichert CM, Misaki A, Gorin PAJ (1973) An extension of the carbohydrate binding specificity of concanavalin A, a lectin isolated from jack bean, with polysaccharides. Arch Biochem Biophys Acta 317:500-504 
Goldstein IJ et al (1976) Carbohydrate binding specificity of concanavalin A. In: Bittiger H, Schnebli HP (eds) Concanavalin $\mathrm{A}$ as a tool. Wiley, London, pp 55-65

Gordon JA, Young RK (1978) The role of concanavalin A dissociation on positive cooperativity of binding with native and fixed erythrocytes. J Biol Chem 254:1932-1937

Gottsater A, Szelag B, Kangro M, Wroblewski M, Sundkvist G (2004) Plasma adiponectin and serum advanced glycated end-products increase and plasma lipid concentrations decrease with increasing duration of type 2 diabetes. Eur J Endocrinol 151(3):361-366

Greer J, Kaufman H, Kalb A (1970) An x-ray crystallographic study of concanavalin A. J Mol Biol 48(2):365-366

Grimaldi J, Sykes B (1975) Concanavalin A: a stopped flow nuclear magnetic resonance study of conformational changes induced by $\mathrm{Mn}^{++}, \mathrm{Ca}^{++}$, and alpha-methyl-D-mannoside. J Biol Chem 250 (5):1618-1624

Guilmot JL, Diot E, Boissier C (2001) Diabetic arteriopathy. Microcirculation, an inevitable therapeutic objective. J Mal Vasc 26(2):135-141

Haruta S, Hanafusa T, Fukase H, Miyajima H, Oki T (2003) An effective absorption behavior of insulin for diabetic treatment following intranasal delivery using porous spherical calcium carbonate in monkeys and healthy human volunteers. Diabetes Technol Ther 5(1):1-9

Inbar M, Sachs L (1969) Structural difference in sites on the surface membrane of normal and transformed cells. Nature 223 (207):710-712

Jack A, Weinzierl J, Kalb A (1971) An x-ray crystallographic study of demetallized concanavalin A. J Mol Biol 58(1):389-395

Kalb AJ, Levitzki A (1968) Metal-binding sites of concanavalin A and their role in the binding of alpha-methyl D-glucopyranoside. Biochem J 109(4):669-672

Kato T , Kiyohara Y, Manaka H, Suzuki K, Hiraizumi M (2004) Clinical study on diabetic neuropathies. Nippon Naika Gakkai Zasshi 93(8):1597-1614

Kim JJ, Park K (2001) Modulated insulin delivery from glucosesensitive hydrogel dosage forms. J Control Release 77(1-2):3947

Kost J, Langer R (2001) Responsive polymeric delivery systems. Adv Drug Delivery Rev 46(1):125-148

Loris R, Maes D, Poortmans F, Wyns L, Bouckaert J (1996) A structure of the complex between concanavalin A and methyl3,6-di- $O$-( $\alpha$-D-mannopyranosyl)- $\alpha$-D-mannopyranoside reveals two binding modes. J Biol Chem 271(48):30614-30618

Mandal DK, Brewer CF (1992) Interactions of concanavalin A with glycoproteins: formation of homogeneous glycoprotein-lectin cross-linked complexes in mixed precipitation systems. Biochemistry 31:12602-12609

Mitchell JB, Nandi CL, McDonald IK, Thornton JM, Price SL (1994) Amino/aromatic interactions in proteins: is the evidence stacked against hydrogen bonding? J Mol Biol 239(2):315-331

Miyata T, Uragami T, Nakamae K (2002) Biomolecule-sensitive hydrogels. Adv Drug Deliv Rev 54(1):79-98

Naismith JH, Field RA (1996) Structural basis of trimannoside recognition by concanavalin A. J Biol Chem 271(2):972-976

Nettleton EJ, Tito P, Sunde M, Bouchard M, Dobson CM, Robinson CV (2000) Characterization of the oligomeric states of insulin in self-assembly and amyloid fibril formation by mass spectrometry. Biophys J 79(2):1053-1065

Neuman P, Cody V, Wojtezak A (2001) Structural basis of negative cooperativity in transthyretin. Acta Biochim Pol 48(4):867-875

Oomen PH, Kant GD, Dullaart RP, Tervaert JW, Reitsma WD, Smit AJ (2004) No effects of acute hyperglycaemia and hyperinsulinaemia on skin microcirculation and endothelial markers in Type II diabetes mellitus. Scand J Clin Lab Invest 64(2):119127

Parker RS, Doyle FJ 3rd, Peppas NA (1999) A model-based algorithm for blood glucose control in type 1 diabetic patients. IEEE Trans Biomed Eng 46(2):148-157

Parker RS, Doyle FJ III, Peppas NA (2001) The intravenous route to blood glucose control. IEEE Eng Med Biol Mag 20(1):65-73

Perutz MF (1993) The role of aromatic rings as hydrogen-bond acceptors in molecular recognition. Phil Trans Roy Soc Serv A 345:105-112

Poretz RD, Goldstein IJ (1970) An examination of the topography of the saccharide binding sites of concanavalin $\mathrm{A}$ and of the forces involved in complexation. Biochemistry 9(14):2890-2896

Qui Y, Park K (2001) Environment-sensitive hydrogels for drug delivery. Adv Drug Deliv Rev 53(3):321-339

Reeke GN Jr, Becker JW, Edelman GM (1975) The covalent and three-dimensional structure of concanavalin A. IV. Atomic coordinates, hydrogen bonding, and quaternary structure. J Biol Chem 250(4):1525-1547

Sherry AD, Cottam GL (1973) Proton relaxation rate and fluorometric studies of manganese and rare earth binding to concanavalin A. Arch Biochem Biophys 156(2):665-672

Sherry AD, Newman AD, Gutz CG (1975) The activation of concanavalin A by lanthanide ions. Biochemistry 14(10):21912196

Tanna S, Taylor MJ, Adams G (1999) Insulin delivery governed by covalently modified lectin-glycogen gels sensitive to glucose. J Pharm Pharmacol 51(10):1093-1098

Taylor MJ, Tanna S, Taylor PM, Adams G (1995) The delivery of insulin from aqueous and non-aqueous reservoirs governed by a glucose sensitive gel membrane. J Drug Target 3(3):209-216

Waksman G, Kominos D, Robertson SC, Pant N, Baltimore D, Birge RB, Cowburn D, Hanafusa H, Mayer BJ, Overduin M, Resh MD, Rios CB, Silverman L, Kuriyan J (1992) Crystal structure of the phosphotyrosine recognition domain $\mathrm{SH} 2$ of $\mathrm{v}$-src complexed with tyrosine-phosphorylated peptides. Nature 358(6388):646653

Wang JL, Cunningham BA, Waxdal MJ, Edelman GM (1975) The covalent and three-dimensional structural of concanavalin A. I. Amino acid sequence of cyanogen bromide fragments F1 and F2. J Biol Chem 250(4):1490-1502

Wang JM, Takeda A, Yang JT, Wu CS (1992) Conformation of concanavalin $\mathrm{A}$ and its fragments in aqueous solution and organic solvent-water mixtures. J Protein Chem 11(2):157-164

Wang C, Stewart RJ, Kopecek J (1999) Hybrid hydrogels assembled from synthetic polymers and coiled-coil protein domains. Nature 397(6718):417-420

Yariv J, Kalb AJ, Levitski A (1968) The interaction of concanavalin A with methyl- $\alpha$-D-glucopyranoside. Biochim Biophys Acta 165:303-305 